\title{
Controls of Methylmercury Bioaccumulation in Forest Floor Food Webs
}

By: Martin Tsz-Ki Tsui, Songnian Liu, Rebecka L. Brasso, Joel D. Blum, Sae Yun Kwon, Yener Ulus, Yabing H. Nollet, Steven J. Balogh, Sue L. Eggert, and Jacques C. Finlay

Martin Tsz-Ki Tsui, Songnian Liu, Rebecka L. Brasso, Joel D. Blum, Sae Yun Kwon, Yener Ulus, Yabing H. Nollet, Steven J. Balogh, Sue L. Eggert, and Jacques C. Finlay. 2019. Controls of Methylmercury Bioaccumulation in Forest Floor Food Webs. Environmental Science \& Technology 53 (5), 2434-2440. DOI: 10.1021/acs.est.8b0605

Made available courtesy of American Chemical Society: http://dx.doi.org/10.1021/acs.est.8b06053

***(C) 2019 American Chemical Society. Reprinted with permission. Published under an ACS AuthorChoice License, which permits copying and redistribution of the article or any adaptations for non-commercial purposes.

\section{Abstract:}

Compared to the extensive research on aquatic ecosystems, very little is known about the sources and trophic transfer of methylmercury $(\mathrm{MeHg})$ in terrestrial ecosystems. In this study, we examine energy flow and trophic structure using stable carbon $\left(\delta^{13} \mathrm{C}\right)$ and nitrogen $\left(\delta^{15} \mathrm{~N}\right)$ isotope ratios, respectively, and $\mathrm{MeHg}$ levels in basal resources and terrestrial invertebrates from four temperate forest ecosystems. We show that $\mathrm{MeHg}$ levels in biota increased significantly $(p<$ $0.01)$ with $\delta^{13} \mathrm{C}$ and $\delta^{15} \mathrm{~N}$ at all sites, implying the importance of both microbially processed diets (with increased $\delta^{13} \mathrm{C}$ ) and trophic level (with increased $\delta^{15} \mathrm{~N}$ ) at which organisms feed, on $\mathrm{MeHg}$ levels in forest floor biota. The trophic magnification slopes of $\mathrm{MeHg}$ (defined as the slope of $\log _{10} \mathrm{MeHg}$ vs $\delta^{15} \mathrm{~N}$ ) for these forest floor food webs $(0.20-0.28)$ were not significantly different $(p>0.05)$ from those observed for diverse temperate freshwater systems $(0.24 \pm 0.07 ; n=78)$, demonstrating for the first time the nearly equivalent efficiencies with which $\mathrm{MeHg}$ moves up the food chain in these contrasting ecosystem types. Our results suggest that in situ production of $\mathrm{MeHg}$ within the forest floor and efficient biomagnification both elevate $\mathrm{MeHg}$ levels in carnivorous invertebrates in temperate forests, which can contribute to significant bioaccumulation of this neurotoxin in terrestrial apex predators.

Keywords: forest food webs | methylmercury | forest ecosystems | bioaccumulation Article:

$* * *$ Note: Full text of article below 


\title{
Controls of Methylmercury Bioaccumulation in Forest Floor Food Webs
}

\author{
Martin Tsz-Ki Tsui, ${ }^{*},, \nabla \odot$ Songnian Liu, ${ }^{\dagger, \nabla}$ Rebecka L. Brasso, ${ }^{\dagger} \nabla$ Joel D. Blum, ${ }^{\S}$ Sae Yun Kwon, \\ Yener Ulus, ${ }^{\dagger}$ Yabing H. Nollet, ${ }^{\perp}$ Steven J. Balogh, ${ }^{\perp} \odot$ Sue L. Eggert, ${ }^{\#}$ and Jacques C. Finlay ${ }^{\otimes}$ \\ ${ }^{\dagger}$ Department of Biology, University of North Carolina at Greensboro, Greensboro, North Carolina 27402, United States \\ ${ }^{\ddagger}$ Department of Zoology, Weber State University, Ogden, Utah 84408, United States \\ ${ }^{\S}$ Department of Earth and Environmental Sciences, University of Michigan, Ann Arbor, Michigan 48109, United States \\ "Division of Environmental Science and Engineering, Pohang University of Science and Technology, Pohang 37673, South Korea \\ ${ }^{\perp}$ Metropolitan Council Environmental Services, St. Paul, Minnesota 55106, United States \\ ${ }^{\#}$ U.S.D.A. Forest Service, Northern Research Station, Grand Rapids, Minnesota 55744, United States \\ ${ }^{\otimes}$ Department of Ecology, Evolution, and Behavior, University of Minnesota, St. Paul, Minnesota 55108, United States
}

Supporting Information

\begin{abstract}
Compared to the extensive research on aquatic ecosystems, very little is known about the sources and trophic transfer of methylmercury $(\mathrm{MeHg})$ in terrestrial ecosystems. In this study, we examine energy flow and trophic structure using stable carbon $\left(\delta^{13} \mathrm{C}\right)$ and nitrogen $\left(\delta^{15} \mathrm{~N}\right)$ isotope ratios, respectively, and $\mathrm{MeHg}$ levels in basal resources and terrestrial invertebrates from four temperate forest ecosystems. We show that $\mathrm{MeHg}$ levels in biota increased significantly $(p<0.01)$ with $\delta^{13} \mathrm{C}$ and $\delta^{15} \mathrm{~N}$ at all sites, implying the importance of both microbially processed diets (with increased $\delta^{13} \mathrm{C}$ ) and trophic level (with increased $\delta^{15} \mathrm{~N}$ ) at which organisms feed, on $\mathrm{MeHg}$ levels in forest floor biota. The trophic magnification slopes of $\mathrm{MeHg}$ (defined as the slope of $\log _{10} \mathrm{MeHg}$ vs $\delta^{15} \mathrm{~N}$ ) for these forest floor food webs $(0.20-0.28)$ were not significantly different $(p>0.05)$ from those observed for diverse temperate freshwater systems $(0.24 \pm 0.07 ; n=78)$, demonstrating for the first

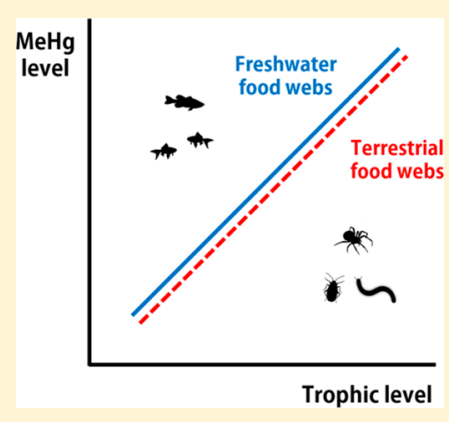
time the nearly equivalent efficiencies with which $\mathrm{MeHg}$ moves up the food chain in these contrasting ecosystem types. Our results suggest that in situ production of $\mathrm{MeHg}$ within the forest floor and efficient biomagnification both elevate MeHg levels in carnivorous invertebrates in temperate forests, which can contribute to significant bioaccumulation of this neurotoxin in terrestrial apex predators.
\end{abstract}

\section{INTRODUCTION}

The concentration of mercury $(\mathrm{Hg})$ in environmental media has been greatly increased by human activities, and long-range atmospheric transport and deposition leads to contamination of virtually all ecosystem types. ${ }^{1,2}$ Anaerobic microbial methylation of deposited inorganic $\mathrm{Hg}$ produces highly toxic methylmercury $(\mathrm{MeHg}){ }^{3}$ which can lead to extensive bioaccumulation and biomagnification in natural food webs, often resulting in elevated levels of $\mathrm{MeHg}$ in apex predators (e.g., wildlife and humans) and causing worldwide health concerns related to this global pollutant. ${ }^{4}$ Aquatic ecosystems, often tied to elevated $\mathrm{Hg}$ methylation in reduced sediments ${ }^{5-7}$ and high $\mathrm{MeHg}$ levels in fish, ${ }^{8-11}$ have been studied extensively for $\mathrm{MeHg}$ production, degradation, and food web bioaccumulation, and include freshwater ponds, lakes, reservoirs, wetlands, streams, ${ }^{8-13}$ and riparian zones with strong aquatic connections. ${ }^{14-18}$

Overall, basal resources play an important role in transferring and incorporating $\mathrm{MeHg}$ into the base of animal food webs, such as herbivores, which ultimately leads to trophic transfer and biomagnification of $\mathrm{MeHg}$ in animals of higher trophic levels. ${ }^{19,20}$ In general, basal resources in various aquatic ecosystems have been found to have much higher $\mathrm{MeHg}$ levels (e.g., seston in Great Lakes with a mean of $33 \mathrm{ng} / \mathrm{g}$ dry wt.; ${ }^{9}$ periphyton in boreal lakes with a mean of $11.0 \mathrm{ng} / \mathrm{g}$ dry wt.; ${ }^{21}$ filamentous algae in a California river with a mean of $19.2 \mathrm{ng} / \mathrm{g}$ dry wt. ${ }^{15}$ ) than their terrestrial counterparts (e.g., foliage and fresh litter in different North American forests with a range of $0.01-0.45 \mathrm{ng} / \mathrm{g}$ dry wt.). ${ }^{22-24}$ Such discrepancies in $\mathrm{MeHg}$ levels between aquatic and terrestrial basal resources may be attributed to the very efficient bioconcentration of dissolved $\mathrm{MeHg}$ from ambient water by aquatic bacteria or algal cells (e.g., to the order of $\left.10^{5}-10^{6}\right),{ }^{25}$ in addition to the elevated production of $\mathrm{MeHg}$ in saturated, anoxic surface sediment, in comparison to dry, oxic forest floors. ${ }^{5-7}$

However, Tsui et al. ${ }^{15}$ analyzed $\mathrm{MeHg}$ in a river and forest food web in a northern California watershed without point

Received: October 26, 2018

Revised: February 5, 2019

Accepted: February 6, 2019

Published: February 7, 2019 
source pollution, and found that $\mathrm{MeHg}$ levels in the forest invertebrates of similar trophic positions were comparable to their local aquatic counterparts (e.g., carnivorous invertebrates had similar ranges of $\mathrm{MeHg}$ levels among rivers and forests), and similar observations were made in another comparison of food webs between a forest and a lake in northern Michigan ${ }^{26}$ (see Supporting Information (SI) Table S1). A few other studies also documented concentrations of total $\mathrm{Hg}$ and $\mathrm{MeHg}$ in terrestrial invertebrates similar to the above two studies. $^{27-30}$ Thus, the processes governing in situ production and trophic transfer of $\mathrm{MeHg}$ in forests, which are largely unknown at present, may play crucial roles in driving bioaccumulation and efficient biomagnification of $\mathrm{MeHg}$ among forest invertebrates, given the very low $\mathrm{MeHg}$ levels in terrestrial basal resources (e.g., fresh litter) compared to their aquatic counterparts (e.g., seston).

In this study, we compared concentrations and trophic transfers of $\mathrm{MeHg}$ in four temperate forest reserves in the United States (SI Table S2), and elucidated their potential dietary and $\mathrm{MeHg}$ sources to the base of forest floor food webs that are independent of aquatic diets (i.e., solely terrestrially based food webs).

\section{MATERIALS AND METHODS}

Study Sites and Sample Collection. Our study sites were in four temperate forest reserves in the continental United States, including: (i) Angelo Coast Range Reserve (Angelo Reserve) of University of California Natural Reserve System in Branscomb, CA; (ii) University of Michigan Biological Station (UMBS) in Pellston, MI; (iii) Coweeta LTER (Coweeta) in Otto, NC; and (iv) Hubbard Brook Experimental Forest LTER (Hubbard Brook) in North Woodstock, NH. The forests are all in the temperate zone but vary in annual temperature and rainfall (SI Table S2). At Coweeta and UMBS, we collected samples among coniferous and deciduous forests while at Angelo Reserve and Hubbard Brook we sampled multiple sites of mixed tree stands.

At each forest, we established 2-5 sampling locations away from nearby streams ( $>27 \mathrm{~m}$; with the majority of sites being $>100 \mathrm{~m}$ ). We determined that these locations received little, if any, aquatic inputs to consumer diets as the abundance of emerged aquatic insects decreases exponentially with distance from stream edge. ${ }^{31}$ We sampled these sites from 2011 to 2015 (see years of sampling in SI Table S2). Within each location, we collected fresh litter wearing clean nonpowder vinyl gloves, and we spent 1-3 days in the field sampling diverse forest invertebrates mainly using three strategies: (i) pitfall traps (during the day and night), (ii) direct capture using tweezers and/or dip nets (during the day), and (iii) light traps (at night) with dry ice to anesthetize biota. For each sampling, we composited samples of the same taxa into a single sample per location during each field trip. Since the collected invertebrates covered a wide range of expected dietary sources and trophic positions, we classified commonly encountered taxa into nine major groups for presentation of the results: moths (Lepidoptera; $n=23$ ), slugs (Gastropoda; $n=8)$, millipedes (Polydesmida/Spirobolida; $n=15$ ), grasshoppers/crickets (Orthoptera; $n=13$ ), harvestman (Opiliones; $n=7$ ), spiders (Araneae; $n=17$ ), beetles (Coleoptera; $n=28$ ), centipedes (Lithobiomorpha; $n=12$ ), and scorpions (Scorpiones; Angelo Reserve only; $n=9$ ). Samples collected in Angelo Reserve (CA) in 2011 and 2012 were previously analyzed for total-Hg ( $\mathrm{THg}$ ), $\mathrm{MeHg}$ and stable $\mathrm{Hg}$ isotope compositions, ${ }^{15,32}$ while all other data have not been reported. A summary showing invertebrate collection (total $=141$ composited samples; including 9 samples not classified above) and number of samples in different sites and groups is presented in SI Table S3.

Sample Processing and Mercury Analyses. Field samples were transported to the laboratory, and frozen immediately at $-20{ }^{\circ} \mathrm{C}$. All samples were later freeze-dried in the laboratory and dried samples were homogenized either by an agate mortar and pestle or a mixer mill (SPEX SamplePrep) cleaned between samples by multiple steps using Barnstead Nanopure water and isopropyl alcohol. All dried and homogenized samples were then stored in acid-cleaned glass vials with PTFE-lined septa (Thermo Scientific) or Hg-free polypropylene centrifuge vials (Falcon or Corning).

Individual samples were extracted for $\mathrm{MeHg}$ using $4.6 \mathrm{M}$ nitric acid at $60{ }^{\circ} \mathrm{C}$ for $12 \mathrm{~h},{ }^{33}$ and the remaining acid digest was then completely oxidized by $\mathrm{KMnO}_{4}$ and $\mathrm{K}_{2} \mathrm{~S}_{2} \mathrm{O}_{8}$ for subsequent $\mathrm{THg}$ analysis. ${ }^{34}$ Sample $\mathrm{MeHg}$ or $\mathrm{THg}$ was quantified by cold vapor atomic fluorescence spectroscopy (Brooks Rand; for both $\mathrm{MeHg}$ and $\mathrm{THg}$ ) or cold vapor atomic absorption spectroscopy (Nippon Instruments Corporation; for THg analysis on samples collected in 2011 and 2012). All acid digestions for $\mathrm{THg}$ and $\mathrm{MeHg}$ analyses were accompanied by standard reference materials (SRMs; NIST-1515 Apple Leaves, NRCC TORT-2 lobster hepatopancreas, NRCC DORM-3 and DORM-4 fish protein) and reagent blanks. All $\mathrm{THg}$ and $\mathrm{MeHg}$ concentrations were reported on a dry weight basis. Detailed analytical procedures and QC/QA data can be found in the SI Methods.

Stable Isotope Analyses and Trophic Level Estimates. All samples were prepared for stable carbon $\left(\delta^{13} \mathrm{C}\right)$ and nitrogen $\left(\delta^{15} \mathrm{~N}\right)$ isotope analyses by gas isotope-ratio mass spectrometry at Colorado Plateau Stable Isotope Laboratory at Northern Arizona University (Flagstaff, AZ), to estimate energy sources and trophic positions, respectively. ${ }^{35,36}$ Trophic levels (TLs) of forest invertebrates in this study were estimated following Post ${ }^{35}$ and Jardine et al.: ${ }^{36}$

$$
\mathrm{TL}_{\text {invertebrate }}=\left(\delta^{15} \mathrm{~N}_{\text {invertebrate }}-\delta^{15} \mathrm{~N}_{\text {freshlitter }}\right) / 3.4+1
$$

where $\delta^{15} \mathrm{~N}_{\text {fresh litter }}$ is the mean value from each forest site while $3.4 \% 0$ is a commonly adopted trophic enrichment factor for stable $\mathrm{N}$ isotopes in food web analyses. ${ }^{36}$ The repeated analyses of SRM NIST-1547 peach leaves $(n=78)$ along with our samples produced 2 SE of $0.018 \%$ for $\delta^{13} \mathrm{C}$ and 2 SE of $0.017 \%$ for $\delta^{15} \mathrm{~N}$.

Statistical Analyses. Sample $\mathrm{MeHg}$ concentrations were log-transformed, and $\log _{10} \mathrm{MeHg}$ was plotted against $\delta^{15} \mathrm{~N}$ values in each forest site to calculate the slope, which is defined as the trophic magnification slope of $\mathrm{MeHg}\left(\mathrm{TMS}_{\mathrm{MeHg}}\right) .{ }^{37}$ All linear and multiple regression analyses were performed using SigmaPlot 12.5 (Systat), in which a normality test (ShapiroWilk) was passed. We compared regression slopes and tested for significant differences using ANCOVA on Prism 5.03 (GraphPad). The significance level for all statistical analyses was $\alpha=0.05$.

\section{RESULTS AND DISCUSSION}

Mercury Concentrations in Litter and Invertebrates. Consistent with published data from other North American forests, ${ }^{23,24,38,39} \mathrm{THg}$ and $\mathrm{MeHg}$ concentrations of all fresh litter samples were low and had relatively narrow ranges, with 
THg ranging between 18 and $61 \mathrm{ng} / \mathrm{g}$ dry wt. $(47.1 \pm 19.4 \mathrm{ng} /$ g; mean \pm S.D.; $n=17$ ) and $\mathrm{MeHg}$ ranging between 0.12 and $0.24 \mathrm{ng} / \mathrm{g}$ dry wt. $(0.17 \pm 0.03 \mathrm{ng} / \mathrm{g})$ in our study forests.

In contrast to fresh litter, we observed a much wider range of THg (3.00-1509 ng/g), MeHg (0.20-291 ng/g), and percentage of $\mathrm{THg}$ as $\mathrm{MeHg}$ (i.e., \% $\mathrm{MeHg}$; $0.70-100 \%$ ) among invertebrate consumers $(n=141)$. Clear group-togroup differences among forest invertebrates were evident for $\mathrm{THg}, \mathrm{MeHg}$, and \% $\mathrm{MeHg}$ (Figure 1). In particular, we found
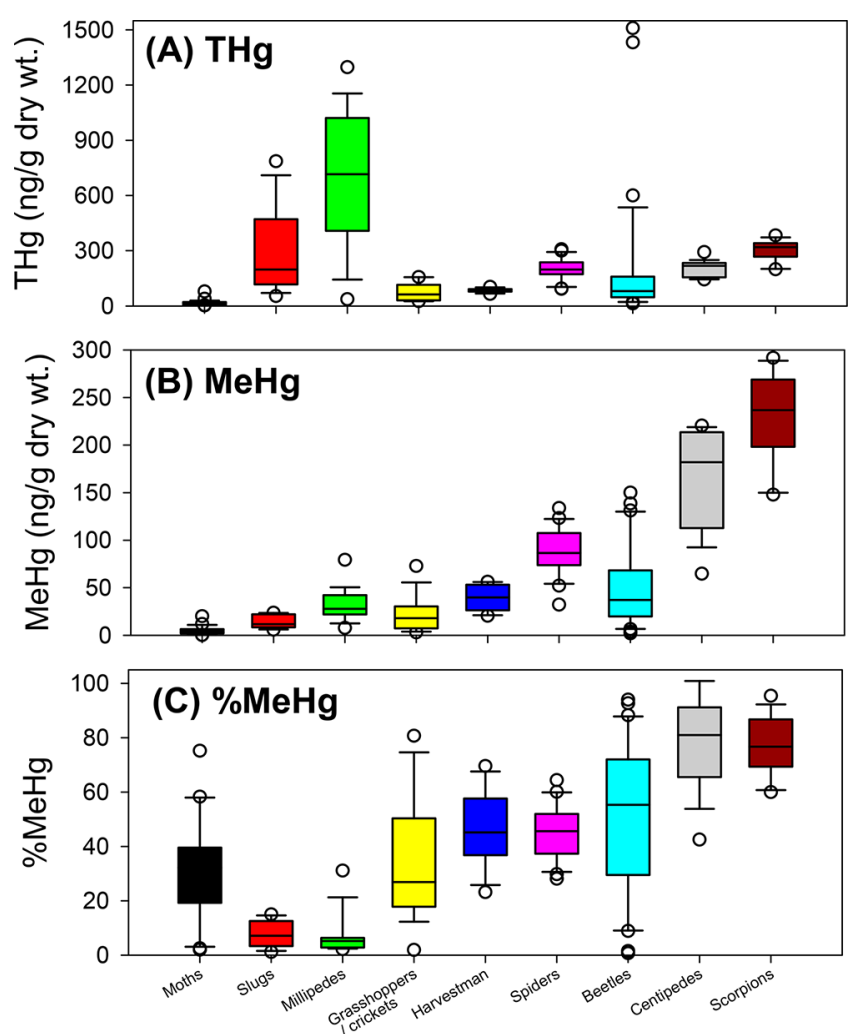

Figure 1. Boxplots of (A) total mercury (THg), (B) methylmercury ( $\mathrm{MeHg}$ ), and (C) percentage of $\mathrm{THg}$ as $\mathrm{MeHg}(\% \mathrm{MeHg}$ ) among nine major groups of invertebrates (on dry weight basis) collected over the four study forests: Angelo Coast Range Reserve in California, University of Michigan Biological Station in Michigan, Coweeta LTER in North Carolina, and Hubbard Brook Experimental Forest in New Hampshire. Number of samples used in the boxplots: $n=23$ for moths, $n=8$ for slugs, $n=15$ for millipedes, $n=13$ for grasshoppers/ crickets, $n=7$ for harvestman, $n=17$ for spiders, $n=28$ for beetles, $n$ $=12$ for centipedes, and $n=9$ for scorpions.

that groups of slugs and millipedes (and three samples of beetles, belonging to the family of Scarabaeidae in two study sites) showed elevated levels of $\mathrm{THg}$ in their tissues (Figure $1 \mathrm{~A}$ ), up to $>1000 \mathrm{ng} / \mathrm{g}$ dry wt., which is considered very high for invertebrates of low TLs in noncontaminated environments. For comparison, THg at such high levels (e.g., $>1000$ $\mathrm{ng} / \mathrm{g}$ dry wt.) in aquatic invertebrates are found almost exclusively in highly contaminated aquatic environment such as streams impacted by $\mathrm{Hg}$ mining. ${ }^{40}$ The reasons underlying the very high inorganic $\mathrm{Hg}$ accumulation in these forest invertebrates are unknown at present but we speculate on the presence of insoluble granules ${ }^{41}$ in the tissues of these forest invertebrates that may sequester inorganic $\mathrm{Hg}$ (and potentially other metals) from their diets; this mechanism has been used to explain the extremely high zinc accumulation in marine barnacles (e.g., with reported values up to $1.6 \%$ of body weight). ${ }^{42}$

$\mathrm{MeHg}$ levels increased with TL from moths to centipedes and scorpions (Figure 1B). Strikingly, when we examined the overall relationship between $\mathrm{THg}$ and $\mathrm{MeHg}$ among these invertebrates, except the groups with very high $\mathrm{THg}$ and low $\mathrm{MeHg}$ (slugs, millipedes, and three samples of beetles belonging to the family of Scarabaeidae), we found a significant and positive relationship over different sites (Figure 2),

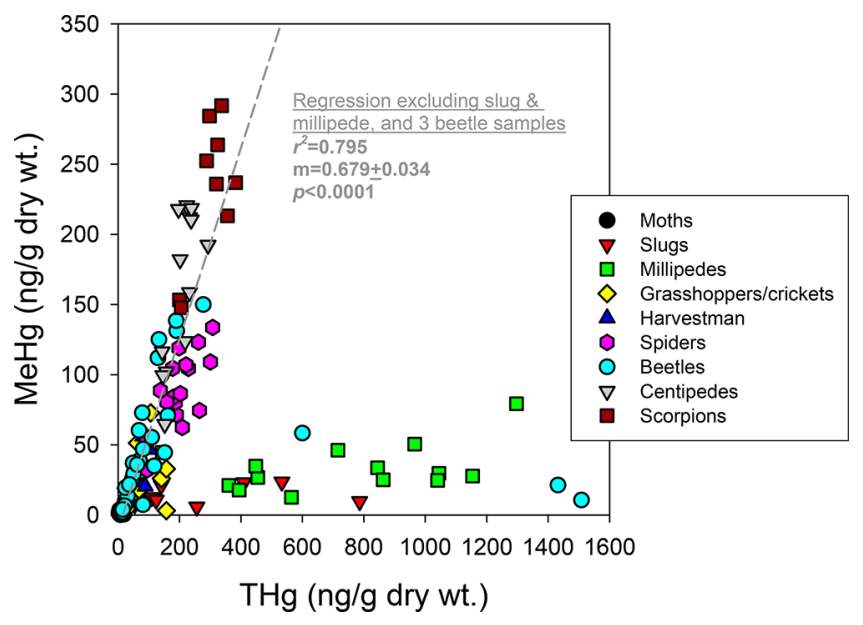

Figure 2. Relationships between total mercury $(\mathrm{THg})$ and methylmercury ( $\mathrm{MeHg}$ ) concentrations (on dry weight basis) in invertebrate samples as separated by groups. Linear regression was performed by excluding the groups of slug and millipede, and three samples of beetle.

indicating that $\mathrm{MeHg}$ is driving overall $\mathrm{THg}$ bioaccumulation for the majority of invertebrate consumers in forest floors. Similar to studies of aquatic macroinvertebrates, ${ }^{11,15,43} \%$ $\mathrm{MeHg}$ spans a wide range among forest invertebrates but \% $\mathrm{MeHg}$ in general becomes elevated at higher TLs (Figure 1C).

Characterization of Food Web Structures Using Stable Isotopes. We found that fresh litter $\left(\mathrm{O}_{\mathrm{i}}\right.$ layer $)$ had little variation in $\delta^{13} \mathrm{C}$ signatures within and among sites $(-29.2 \pm 0.83 \%$; mean \pm S.D.; $n=17$; SI Tables S4-S7), which was similar to $\mathrm{C}_{3}$ plants around the world $(-25$ to $-29 \%$ o. ${ }^{44}$ Compared to fresh litter, invertebrate $\delta^{13} \mathrm{C}$ values varied more widely (from -34.5 to $-21.4 \%$ ) with the distribution of values skewed toward much higher values relative to those of litter $(-29.2 \pm 0.83 \% \circ ; n=17)$, and with an overall mean of $-26.0 \%$ among all invertebrate samples $(n$ $=141$; Figure 3 ). The exception to this was the group of moths in which we found a mean $( \pm$ S.D. $)$ of $-29.3 \pm 2.04 \%$ o $(n=$ 22) (SI Figure S1) that matches well to those of fresh litter, implying that there may not be a direct trophic connection between moths and many of the other forest invertebrates that we investigated.

Because the average trophic enrichment of $\delta^{13} \mathrm{C}$ is expected to be $\sim 0.5 \%$ o per trophic level (TL) in natural food webs, ${ }^{45}$ these data suggested that fresh litter itself is not the major, direct diet for many of these forest invertebrates (excluding moths). Similar results were found in a previous study on forest floor food webs in Switzerland. ${ }^{46}$ In fact, incorporation of decomposed litter into soil organic matter could elevate the $\delta^{13} \mathrm{C}$ value of organic carbon by approximately $1.6-2.3 \%,{ }^{47}$ and the assimilation of organic carbon by saprotrophic fungi can even further increase $\delta^{13} \mathrm{C}$ values of residual organic 

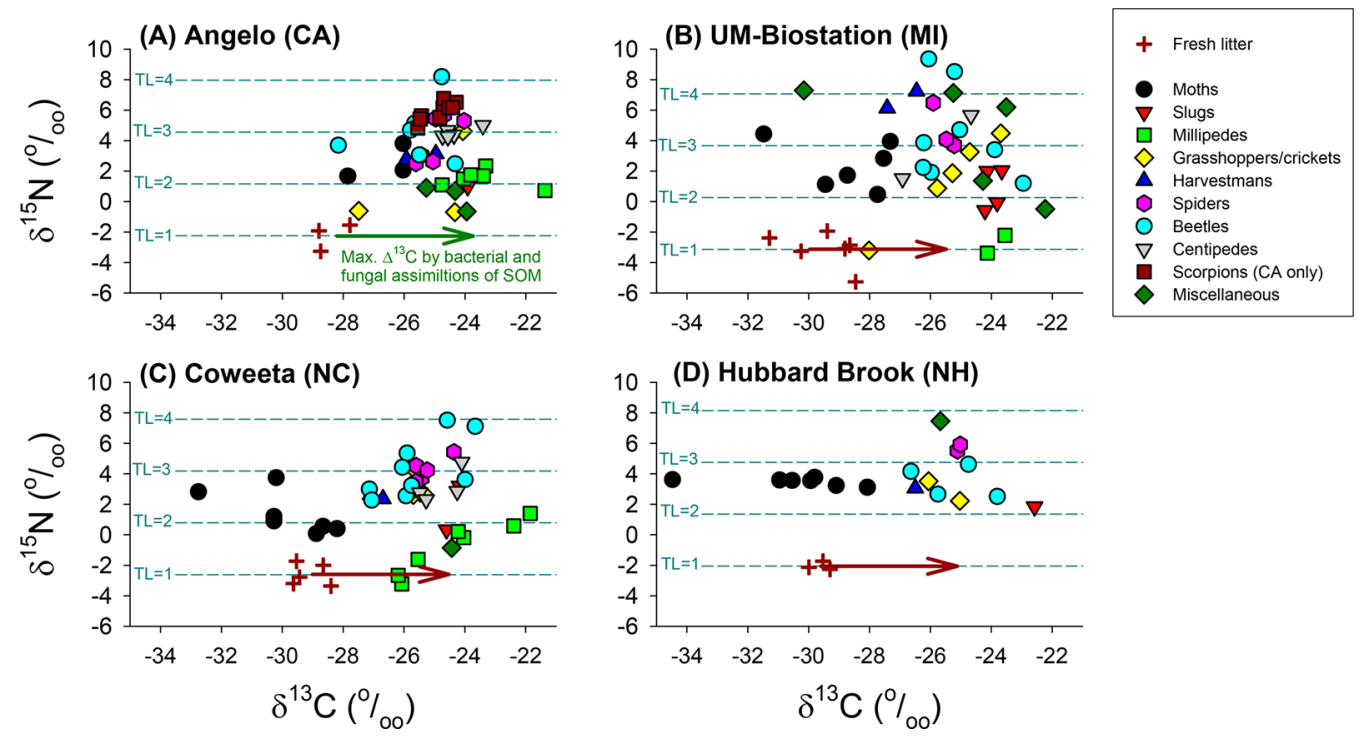

Figure 3. Relationship between stable carbon isotope compositions $\left(\delta^{13} \mathrm{C}\right.$; as a proxy of dietary sources) and nitrogen isotope compositions $\left(\delta^{15} \mathrm{~N}\right.$; as a proxy of trophic positions) of biota samples in each study forest: (A) Angelo Coast Range Reserve in California, (B) University of Michigan Biological Station in Michigan, (C) Coweeta LTER in North Carolina, and (D) Hubbard Brook Experimental Forest in New Hampshire. The arrows indicate the maximum enrichment of $\delta^{13} \mathrm{C}$ for litter decomposition and incorporation into soil organic matter (SOM) ${ }^{47}$ and for the utilization of SOM by saprotrophic fungi ${ }^{48}$ from fresh litter. The dashed lines indicate the calculated trophic level (TL) at each forest.

carbon by approximately $3.0 \%$ (see arrows in Figure 3 to denote the maximum enrichment of $\left.\delta^{13} \mathrm{C}\right){ }^{48}$ Some direct evidence connecting $\delta^{13} \mathrm{C}$ in microbial diets of forest invertebrates comes from fungal samples at our California forest site (Angelo Reserve). Specifically, $\delta^{13} \mathrm{C}$ values of soil hyphae and fruiting bodies were found to be $-24.69 \pm 1.40 \%$ o and $-24.82 \pm 0.09 \%$ ( $n=2$ each $)$, respectively, which matches well to those of invertebrate consumers in this and other study sites (Figure 3). Thus, microbial (bacterial and/or fungal) decomposition of organic matter can lead to increases of $\delta^{13} \mathrm{C}$, and consumption of these dietary sources with higher $\delta^{13} \mathrm{C}$ values likely account for the large enrichment of invertebrate $\delta^{13} \mathrm{C}$ relative to that of $\mathrm{C} 3$ litter in these forests.

We used the site-specific mean $\delta^{15} \mathrm{~N}$ values of basal resources $(-3.14$ to $-2.05 \%$ ) to estimate the TL of invertebrate consumers by adopting a mean trophic enrichment of $3.4 \%$ per TL (Figure 3). ${ }^{36}$ Overall, our sampled invertebrate food webs have TL spanning from 0.9 to $4.5(n=$ 143) among the four study forests (shown by horizontal dashed lines in Figure 3).

Influence of Food Web Structures on Methylmercury Bioaccumulation. Since $\mathrm{MeHg}$ is the main $\mathrm{Hg}$ species that biomagnifies, ${ }^{37}$ here we focus on the trophic transfer of $\mathrm{MeHg}$ (rather than $\mathrm{THg}$ ) in forest food webs. As invertebrates at higher TLs tended to have $\delta^{13} \mathrm{C}$ shifted toward higher values among sites (Figure 3 ), it is not surprising to observe highly significant and positive relationships $(p<0.01)$ between $\delta^{13} \mathrm{C}$ and $\mathrm{MeHg}$ in all sites (Figure $4 \mathrm{~A}-\mathrm{D}$ ). Thus, we suggest that invertebrates with higher $\delta^{13} \mathrm{C}$ values than fresh litter might consume diets/prey based on carbon derived from more decomposed organic matter, which can be associated with higher $\mathrm{MeHg}$ content ${ }^{22,23}$ and higher $\delta^{13} \mathrm{C}$ values (and our $\delta^{13} \mathrm{C}$ measurements of fungal biomasses at Angelo Reserve). ${ }^{47,48}$

Consistent with biomagnification of $\mathrm{MeHg}$ widely observed in aquatic food webs, all forest invertebrate consumers showed highly significant increases of $\mathrm{MeHg}(p<0.0001)$ along the food chain in each site with increasing $\delta^{15} \mathrm{~N}$ (Figure 4E-H). We calculated $\mathrm{TMS}_{\mathrm{MeHg}}$ (defined as slope of $\log _{10} \mathrm{MeHg}$ vs $\delta^{15} \mathrm{~N}$; including fresh litter and invertebrate samples) among the four forest sites and found only a small range from 0.202 to 0.281 , with the lowest value at the UMBS (MI) and the highest in mixed forests at Hubbard Brook $(\mathrm{NH})$. We did not detect significant differences in $\mathrm{TMS}_{\mathrm{MeHg}}$ among the four forest floor food webs $(p>0.05)$. Importantly, the $\mathrm{TMS}_{\mathrm{MeHg}}$ values estimated from four temperate forests were within the range (or within $1 \mathrm{SD}$ of the mean value) reported by a recent data synthesis of freshwater studies in temperate regions in which the authors found a mean $\mathrm{TMS}_{\mathrm{MeHg}}$ of $0.24 \pm 0.07(n=78 ; 1$ SD). ${ }^{37}$ We also did not find significant differences in $\mathrm{TMS}_{\mathrm{MeHg}}$ between our forest floor food webs and the diverse aquatic food webs compiled by Lavoie et al. ${ }^{37}(p>0.05)$. Thus, these results demonstrate for the first time that $\mathrm{MeHg}$ has a similar efficiency for biomagnification along freshwater vs forest floor food webs under similar climate conditions (i.e., temperate).

We also performed multiple regression analyses to assess the relative contributions of $\delta^{13} \mathrm{C}$ (after correction for trophic enrichment) ${ }^{45}$ and $\delta^{15} \mathrm{~N}$ to $\mathrm{MeHg}$ levels in invertebrates. We showed that both isotope signatures were significant predictors $(p<0.001)$ of $\mathrm{MeHg}$ levels in forest biota, but $\delta^{15} \mathrm{~N}$ was still a stronger predictor (higher $t$ statistic values) than $\delta^{13} \mathrm{C}$ (SI Table S8). This result underscores the importance of TL and the internal microbial processing of dietary sources (and the associated in situ $\mathrm{MeHg}$ production) on the ultimate $\mathrm{MeHg}$ bioaccumulation in forest invertebrate food webs.

Explanations for "Higher-than-Expected" Methylmercury Levels in Forest Invertebrates. As discussed above, the reported $\mathrm{MeHg}$ tissue concentrations are similar between terrestrial carnivorous invertebrates (from limited studies) and freshwater carnivorous invertebrates in the same systems unaffected by point sources or wetlands (SI Table S1). The question remains: why and how $\mathrm{MeHg}$ is taken up at such levels in terrestrial invertebrates given that the basal resources (i.e., fresh litter) have very low $\mathrm{MeHg}$ levels (i.e., $<0.2 \mathrm{ng} / \mathrm{g}$ ) 

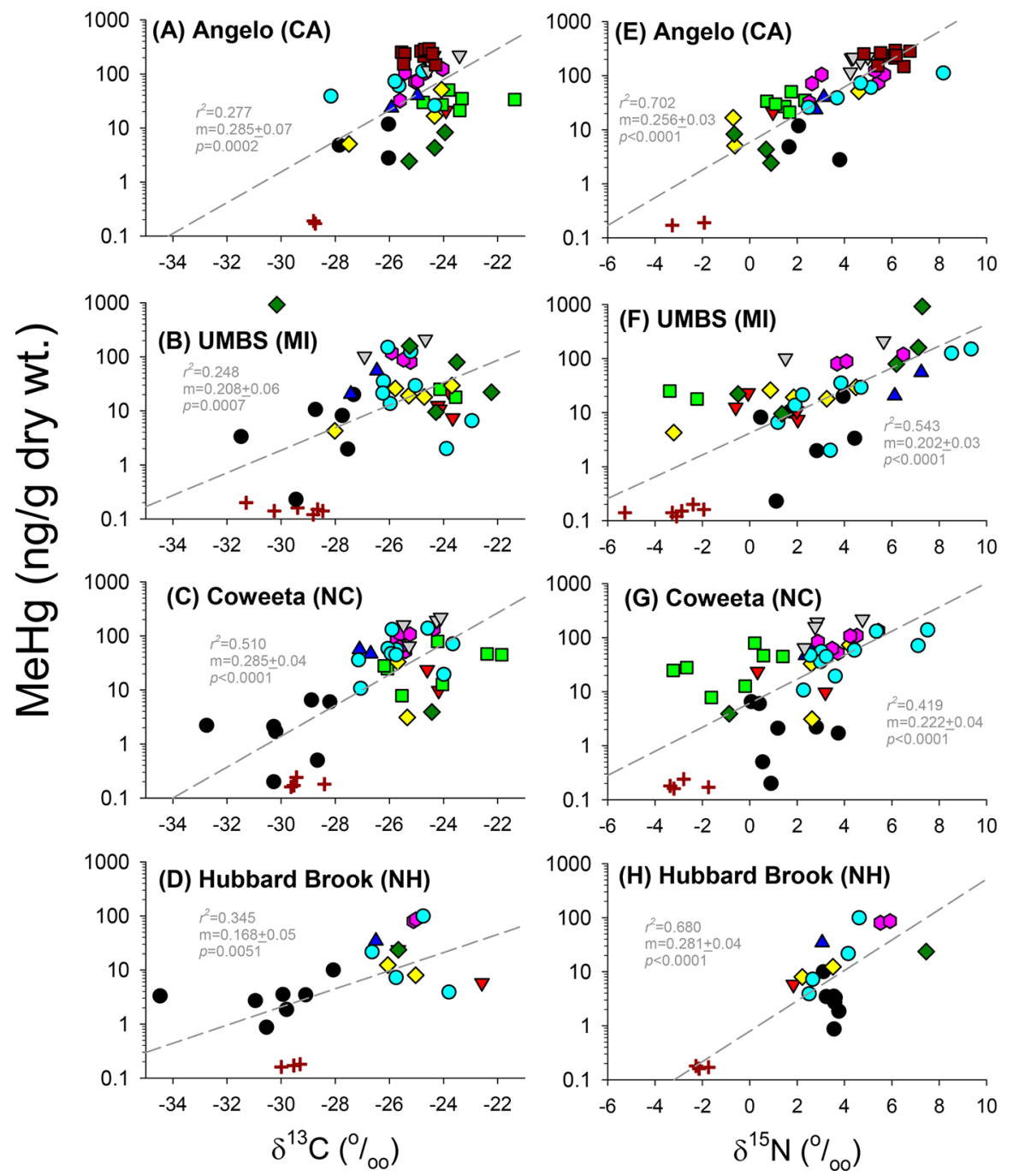

Figure 4. Relationships between stable carbon isotope compositions $\left(\delta^{13} \mathrm{C}\right.$; uncorrected for trophic enrichment; as a proxy of dietary sources) and methylmercury $(\mathrm{MeHg}$ ) tissue concentrations (on dry weight basis) of biota samples in each study forest: (A) Angelo Coast Range Reserve in California, (B) University of Michigan Biological Station in Michigan, (C) Coweeta LTER in North Carolina, and (D) Hubbard Brook Experimental Forest in New Hampshire. Relationships between stable nitrogen isotope compositions $\left(\delta^{15} \mathrm{~N}\right.$; as a proxy of trophic positions) and $\mathrm{MeHg}$ tissue concentrations of biota samples in each study forests: (E) Angelo Coast Range Reserve in California, (F) University of Michigan Biological Station in Michigan, (G) Coweeta LTER in North Carolina, and (H) Hubbard Brook Experimental Forest in New Hampshire.

compared to aquatic basal resources? Given the strikingly similar $\mathrm{TMS}_{\mathrm{MeHg}}$ between temperate forest and freshwater ecosystems, we argue that the actual diets for the base of forest invertebrate food webs must have considerably higher $\mathrm{MeHg}$ levels than those found in fresh litter (i.e., $\gg 0.1-0.2 \mathrm{ng} / \mathrm{g}$ ) for the invertebrates to achieve $\mathrm{MeHg}$ levels comparable to aquatic consumers at the same trophic levels. Here, we provide two different (but mutually inclusive) reasons that alone or in combination may explain the "higher-than-expected" $\mathrm{MeHg}$ levels in forest invertebrates.

First, $\mathrm{MeHg}$ can be generated during organic matter decomposition processes. While we lack direct data to address this mechanism, some support is found from observational and experimental studies that have found that partially decomposed organic matter contained higher $\mathrm{MeHg}$ levels than fresh organic matter in the forest floor. For example, Obrist ${ }^{23}$ found that decomposed litter layers $\left(\mathrm{O}_{e}\right.$ and $\mathrm{O}_{a}$ horizons $)$ had elevated (10 times higher), yet variable, $\mathrm{MeHg}$ levels compared to fresh litter $\left(\mathrm{O}_{\mathrm{i}}\right.$ horizon). Hall and St. Louis ${ }^{22}$ similarly showed that tree litter and wood block placed in unsaturated forest soils in a decomposition experiment developed higher (4-30 times higher) $\mathrm{MeHg}$ levels over time (see values in SI Table S1).

Further support for a role of litter decomposition processes on terrestrial $\mathrm{MeHg}$ production comes from our $\delta^{13} \mathrm{C}$ data (Figure 3 ), which strongly suggests influences of microbial degradation of litter (by bacteria and/or fungi) within the forest floor. Reliance on highly decomposed organic matter and its associated fungal and microbial biomass would be expected to increase $\delta^{13} \mathrm{C}$ of the organic matter diets of the invertebrates. ${ }^{47,48}$ For example, mycorrhizae are known to be very effective at decomposing organic carbon and remineralizing nutrients in forested ecosystems. ${ }^{49}$ Mercury methylation has also been demonstrated in some fungal groups under controlled conditions, ${ }^{50}$ likely through the association of ubiquitous anaerobic microbes possessing $h g c A / h g c B$ gene clusters. ${ }^{51}$ Thus, we hypothesize that decomposition of the soil organic matter pool (especially with the participation of tree roots or their exudates) ${ }^{46}$ introduces additional $\mathrm{MeHg}$ to the diets of invertebrates (i.e., decomposed organic matter) that 
can be routed into terrestrial food chains, as shown in the elevated and highly variable $\mathrm{MeHg}$ levels in decomposed plant materials (SI Table S1). Additional research is needed to identify the spatial distribution of these biogeochemical pools of $\mathrm{MeHg}$ in forest floors; we suggest that this mechanism could provide higher $\mathrm{MeHg}$ dietary inputs to forest food webs.

A second possible explanation for higher than expected $\mathrm{MeHg}$ in terrestrial invertebrates is the high TLs of some of the terrestrial invertebrate consumers found in this study (up to $\mathrm{TL}=4.0$ or higher) (Figure 3 ), which may be explained by the prevalence of detrital (or "brown") food webs in forest floors. ${ }^{52}$ The presence of microbial components would lengthen (or inflate) the trophic food chain as detritus would be initially transformed into bacterial and fungal biomass, ${ }^{52}$ which can be consumed by very small predators (e.g., protists) resulting in elevated $\mathrm{MeHg}$ levels through biomagnification. ${ }^{37}$ Since the two processes discussed above can operate at the same time, we suggest a combination of them can lead to higher $\mathrm{MeHg}$ levels in terrestrial invertebrate consumers, but their relative importance needs to be better resolved by additional research.

In summary, the work presented here shows that $\mathrm{MeHg}$ biomagnifications (i.e., the increase per TL) are similar among forest floor and freshwater food webs in temperate regions. We do not know at present if these findings can be extrapolated to other terrestrial ecosystems such as grasslands and tropical rainforests. However, our work shows that apex animal consumers such as birds and mammals in temperate forests can still obtain large amounts of $\mathrm{MeHg}$ from terrestrial invertebrate prey at high TLs. It should be noted that terrestrial arthropods have a very large global biomass (i.e., 0.2 Gt C), ${ }^{53}$ thus they can represent a large, concentrated pool of $\mathrm{MeHg}$ (i.e., up to sub-ppm level in tissues) that is readily available to move up the food chain in forest ecosystems.

\section{ASSOCIATED CONTENT}

\section{S Supporting Information}

The Supporting Information is available free of charge on the ACS Publications website at DOI: 10.1021/acs.est.8b06053.

Detailed analytical methods for total mercury and methylmercury analyses, QC/QA data, compilation of methylmercury levels in aquatic and terrestrial carnivorous invertebrates from two previous studies, basic characteristics of the forest study sites, summary of sample collection in this study, raw data for individual samples, results of multiple linear regressions between stable isotopes and methylmercury levels in forest floor food webs, and a comparison of stable carbon isotope ratios among moths vs all invertebrates in this study (PDF).

\section{AUTHOR INFORMATION}

\section{Corresponding Author}

*Phone: 336-256-0087; e-mail: tmtsui@uncg.edu.

\section{ORCID}

Martin Tsz-Ki Tsui: 0000-0003-2002-1530

Joel D. Blum: 0000-0001-5389-8633

Steven J. Balogh: 0000-0003-2606-0450

\section{Author Contributions}

$\nabla$ Equal contribution/cofirst authors.

\section{Notes}

The authors declare no competing financial interest.

\section{ACKNOWLEDGMENTS}

This study was supported by a National Science Foundation award to M.T.K.T. (DEB-1354811) and J.D.B. (DEB1353850), and funding from the University of North Carolina at Greensboro and the University of Michigan. We thank G. Woerndle, P. Blum, J. Alva, and G. Rios-Sotelo for assisting sample collection in the field. We appreciate the constructive comments from two anonymous reviewers. We also acknowledge the logistical support of research field stations for this study, including Angelo Coast Range Reserve, University of Michigan Biological Station, Hubbard Brook Ecosystem Study, and Coweeta LTER.

\section{REFERENCES}

(1) Mason, R. P.; Fitzgerald, W. F.; Morel, F. M. M. The biogeochemical cycling of elemental mercury: Anthropogenic influences. Geochim. Cosmochim. Acta 1994, 58, 3191-3198.

(2) Fitzgerald, W. F.; Engstrom, D. R.; Mason, R. P.; Nater, E. A. The case for atmospheric mercury contamination in remote areas. Environ. Sci. Technol. 1998, 32, 1-7.

(3) Gilmour, C. C.; Henry, E. A.; Mitchell, R. Sulfate stimulation of mercury methylation in freshwater sediments. Environ. Sci. Technol. 1992, 26, 2281-2287.

(4) Scheuhammer, A. M.; Meyer, M. W.; Sandheinrich, M. B.; Murray, M. W. Effects of environmental methylmercury on the health of wild birds, mammals, and fish. Ambio 2007, 36, 12-18.

(5) St Louis, V. L.; Rudd, J. W. M.; Kelly, C. A.; Beaty, K. G.; Bloom, N. S.; Flett, R. J. Importance of wetlands as sources of methyl mercury. Can. J. Fish. Aquat. Sci. 1994, 51, 1065-1076.

(6) Grigal, D. F. Mercury sequestration in forests and peatlands: A review. J. Environ. Qual. 2003, 32, 393-405.

(7) Hintelmann, H.Organomercurials: Their formation and pathways in the environment. In Metal Ions in Life Sciences; Sigel, A., Sigel, H., Sigel, R. K. O. Eds.; Royal Society of Chemistry: Cambridge, England, 2010; Vol. 7, pp 365- 401.

(8) Cabana, G.; Rasmussen, J. B. Modeling food-chain structure and contaminant bioaccumulation using stable nitrogen isotopes. Nature 1994, 372, 255-257.

(9) Watras, C. J.; Back, R. C.; Halvorsen, S.; Hudson, R. J. M.; Morrison, K. A.; Wente, S. P. Bioaccumulation of mercury in pelagic freshwater food webs. Sci. Total Environ. 1998, 219, 183-208.

(10) Peterson, S. A.; Van Sickle, J.; Herlihy, A. T.; Hughes, R. M. Mercury concentration in fish from streams and rivers throughout the western United States. Environ. Sci. Technol. 2007, 41, 58-65.

(11) Chasar, L. C.; Scudder, B. C.; Stewart, A. R.; Bell, A. H.; Aiken, G. R. Mercury cycling in stream ecosystems. 3. Trophic dynamics and methylmercury bioaccumulation. Environ. Sci. Technol. 2009, 43, 2733-2739.

(12) Seller, P.; Kelly, C. A.; Rudd, J. W. M.; MacHutchon, A. R. Photodegradation of methylmercury in lakes. Nature 1996, 380, 694697.

(13) Tsui, M. T. K.; Finlay, J. C.; Nater, E. A. Mercury bioaccumulation in a stream network. Environ. Sci. Technol. 2009, 43, 7016-7022.

(14) Cristol, D. A.; Brasso, R. L.; Condon, A. M.; Fovargue, R. E.; Friedman, S. L.; Hallinger, K. K.; Monroe, A. P.; White, A. E. The movement of aquatic mercury through terrestrial food webs. Science 2008, 320, 335-336.

(15) Tsui, M. T. K.; Blum, J. D.; Finlay, J. C.; Balogh, S. J.; Kwon, S. Y.; Nollet, Y. H. Sources and transfers of methylmercury in adjacent river and forest food webs. Environ. Sci. Technol. 2012, 46, 1095710964.

(16) Speir, S. L.; Chumchal, M. M.; Drenner, R. W.; Cocke, W. G.; Lewis, M. E.; Whitt, H. J. Methyl mercury and stable isotopes of nitrogen reveal that a terrestrial spider has a diet of emergent aquatic insects. Environ. Toxicol. Chem. 2014, 33, 2506-2509. 
(17) Bartrons, M.; Gratton, C.; Spiesman, B. J.; Vander Zanden, M. J. Taking the trophic bypass: Aquatic-terrestrial linkage reduces methylmercury in a terrestrial food web. Ecol. Appl. 2015, 25, 151159.

(18) Becker, D. J.; Chumchal, M. M.; Broders, H. G.; Korstian, J. M.; Clare, E. L.; Rainwater, T. R.; Platt, S. G.; Simmons, N. B.; Fenton, M. B. Mercury bioaccumulation in bats reflects dietary connectivity to aquatic food webs. Environ. Pollut. 2018, 233, 1076-1085.

(19) Pickhardt, P. C.; Folt, C. L.; Chen, C. Y.; Klaue, B.; Blum, J. D. Algal blooms reduce the uptake of toxic methylmercury in freshwater food webs. Proc. Natl. Acad. Sci. U. S. A. 2002, 99, 4419-4423.

(20) Tsui, M. T. K.; Wang, W. X. Uptake and elimination routes of inorganic mercury and methylmercury in Daphnia magna. Environ. Sci. Technol. 2004, 38, 808-816.

(21) Desrosiers, M.; Planas, D.; Mucci, A. Total mercury and methylmercury accumulation in periphyton of Boreal Shield Lakes: Influence of watershed physiographic characteristics. Sci. Total Environ. 2006, 355, 247-258.

(22) Hall, B. D.; St Louis, V. L. Methylmercury and total mercury in plant litter decomposing in upland forests and flooded landscapes. Environ. Sci. Technol. 2004, 38, 5010-5021.

(23) Obrist, D. Mercury distribution across 14 U.S. forests. Part II: patterns of methyl mercury concentrations and areal mass of total and methyl mercury. Environ. Sci. Technol. 2012, 46, 5921-5930.

(24) Tabatchnick, M. D.; Nogaro, G.; Hammerschmidt, C. R Potential sources of methylmercury in tree foliage. Environ. Pollut. 2012, 160, 82-87.

(25) Pickhardt, P. C.; Fisher, N. S. Accumulation of inorganic and methylmercury by freshwater phytoplankton in two contrasting water bodies. Environ. Sci. Technol. 2007, 41, 125-131.

(26) Kwon, S. Y.; Blum, J. D.; Nadelhoffer, K. J.; Dvonch, J. T.; Tsui, M. T. K. Isotopic study of mercury sources and transfer between a freshwater lake and adjacent forest food web. Sci. Total Environ. 2015, 532, 220-229.

(27) Zheng, D. M.; Wang, Q. C.; Zhang, Z. S.; Zheng, N.; Zhang, X. W. Bioaccumulation of total and methyl mercury by arthropods. Bull. Environ. Contam. Toxicol. 2008, 81, 95-100.

(28) Rimmer, C. C.; Miller, E. K.; McFarland, K. P.; Taylor, R. J.; Faccio, S. D. Mercury bioaccumulation and trophic transfer in the terrestrial food web of a montane forest. Ecotoxicology 2010, 19, 697709.

(29) Rieder, S. R.; Brunner, I.; Horvat, M.; Jacobs, A.; Frey, B. Accumulation of mercury and methylmercury by mushrooms and earthworms from forest soils. Environ. Pollut. 2011, 159, 2861-2869.

(30) Tavshunsky, I.; Eggert, S. L.; Mitchell, C. P. J. Accumulation of methylmercury in invertebrates and masked shrews (Sorex cinereus) at an upland forest-peatland interface in northern Minnesota, USA. Bull. Environ. Contam. Toxicol. 2017, 99, 673-678.

(31) Baxter, C. V.; Fausch, K. D.; Saunders, W. C. Tangled webs: Reciprocal flows of invertebrate prey link streams and riparian zones. Freshwater Biol. 2005, 50, 201-220.

(32) Tsui, M. T. K.; Blum, J. D.; Finlay, J. C.; Balogh, S. J.; Nollet, Y. H.; Palen, W. J.; Power, M. E. Variation in terrestrial and aquatic sources of methylmercury in stream predators as revealed by stable mercury isotopes. Environ. Sci. Technol. 2014, 48, 10128-10135.

(33) Hammerschmidt, C. R.; Fitzgerald, W. F. Methylmercury in mosquitoes related to atmospheric mercury deposition and contamination. Environ. Sci. Technol. 2005, 39, 3034-3039.

(34) Tsui, M. T. K.; Adams, E. M.; Jackson, A. K.; Evers, D. C.; Blum, J. D.; Balogh, S. J. Understanding sources of methylmercury in songbirds with stable mercury isotopes: Challenges and future directions. Environ. Toxicol. Chem. 2018, 37, 166-174.

(35) Post, D. M. Using stable isotopes to estimate trophic position: Models, methods, and assumptions. Ecology 2002, 83, 703-718.

(36) Jardine, T. D.; Kidd, K. A.; Fisk, A. T. Applications, considerations, and sources of uncertainty when using stable isotope analysis in ecotoxicology. Environ. Sci. Technol. 2006, 40, 7501-7511.

(37) Lavoie, R. A.; Jardine, T. D.; Chumchal, M. M.; Kidd, K. A.; Campbell, L. M. Biomagnification of mercury in aquatic food webs: A worldwide meta-analysis. Environ. Sci. Technol. 2013, 47, 1338513394.

(38) Obrist, D.; Johnson, D. W.; Lindberg, S. E.; Luo, Y.; Hararuk, O.; Bracho, R.; Battles, J. J.; Dail, D. B.; Edmonds, R. L.; Monson, R. K.; Ollinger, S. V.; Pallardy, S. G.; Pregitzer, K. S.; Todd, D. E. Mercury distribution across 14 US forests. Part I: Spatial patterns of concentrations in biomass, litter, and soils. Environ. Sci. Technol. 2011, 45, 3974-3981.

(39) Tsui, M. T. K.; Finlay, J. C.; Nater, E. A. Effects of stream water chemistry and tree species on release and methylation of mercury during litter decomposition. Environ. Sci. Technol. 2008, 42, 86928697.

(40) Žižek, S.; Horvat, M.; Gibičar, D.; Fajon, V.; Toman, M. J. Bioaccumulation of mercury in benthic communities of a river ecosystem affected by mercury mining. Sci. Total Environ. 2007, 377, 407-415.

(41) Walker, G.; Rainbow, P. S.; Foster, P.; Crisp, D. J. Barnacles: Possible indicators of zinc pollution? Mar. Biol. 1975, 30, 57-65.

(42) Rainbow, P. S.; Smith, B. D. In The Marine Flora and Fauna of Hong Kong and Southern China III; Morton, B. S., Ed.; Hong Kong University Press: Hong Kong, 1992; pp 585-597.

(43) Haro, R. J.; Bailey, S. W.; Northwick, R. M.; Rolfhus, K. R.; Sandheinrich, M. B.; Wiener, J. G. Burrowing dragonfly larvae as biosentinels of methylmercury in freshwater food webs. Environ. Sci. Technol. 2013, 47, 8148-8156.

(44) O'Leary, M. H. Carbon isotopes in photosynthesis: Fractionation techniques may reveal new aspects of carbon dynamics in plants. BioScience 1988, 38, 328-336.

(45) McCutchan, J. H.; Lewis, W. M.; Kendall, C.; McGrath, C. C. Variation in trophic shift for stable isotope ratios of carbon, nitrogen, and sulfur. Oikos 2003, 102, 378-390.

(46) Pollierer, M. M.; Langel, R.; Körner, C.; Maraun, M.; Scheu, S. The underestimated importance of belowground carbon input for forest soil animal food webs. Ecol. Lett. 2007, 10, 729-736.

(47) Buchmann, N.; Kao, W. Y.; Ehleringer, J. Influence of stand structure on carbon-13 of vegetation, soils, and canopy air within deciduous and evergreen forests in Utah, United States. Oecologia 1997, 110, 109-119.

(48) Hyodo, F. Use of stable carbon and nitrogen isotopes in insect trophic ecology. Entomol. Sci. 2015, 18, 295-312.

(49) Högberg, P.; Nordgren, A.; Buchmann, N.; Taylor, A. F. S.; Ekblad, A.; Högberg, M. N.; Nyberg, G.; Ottosson-Löfvenius, M.; Read, D. J. Large-scale forest girdling shows that current photosynthesis drives soil respiration. Nature 2001, 411, 789-792.

(50) Fischer, R. G.; Rapsomanikis, S.; Andreae, M. O.; Baldi, F. Bioaccumulation of methylmercury and transformation of inorganic mercury by macrofungi. Environ. Sci. Technol. 1995, 29, 993-999.

(51) Podar, M.; Gilmour, C. C.; Brandt, C. C.; Soren, A.; Brown, S. D.; Crable, B. R.; Palumbo, A. V.; Somenahally, A. C.; Elias, D. A. Global prevalence and distribution of genes and microorganisms involved in mercury methylation. Sci. Adv. 2015, 1, No. e1500675.

(52) Steffan, S. A.; Chikaraishi, Y.; Dharampal, P. S.; Pauli, J. N.; Guédot, C.; Ohkouchi, N. Unpacking brown food-webs: Animal trophic identity reflects rampant microbivory. Ecol. Evol. 2017, 7, $3532-3541$

(53) Bar-On, Y. M.; Phillips, R.; Milo, R. The biomass distribution on Earth. Proc. Natl. Acad. Sci. U. S. A. 2018, 115, 6506-6511. 